\title{
Methylprednisolone treatment of experimental spinal cord injury
}

\author{
A Iwai MD ${ }^{1} \mathrm{~W}$ W Monafo $\mathrm{MD},{ }^{1} \mathrm{~S} \mathrm{G}$ Eliasson $\mathrm{MD} \mathrm{PhD}^{2}$ \\ Departments of ${ }^{1}$ Surgery and ${ }^{2}$ Neurology, Washington University School of Medicine, \\ St Louis, Missouri, USA.
}

\begin{abstract}
Lipid peroxidation has been identified as a deleterious consequence of contusive spinal cord trauma and of thermal injury. The L3-L6 spinal cord segment was thermally injured using a radiofrequency heating chamber mounted on the vertebral column of anesthetized rats. Hind limb function was assessed 2 hours later. A bolus of methylprednisolone (MP, $30 \mathrm{mg} / \mathrm{kg}$ ) was then given intravenously, followed by $5.4 \mathrm{mg} / \mathrm{kg} / \mathrm{hr}$ MP for 6 or 24 hours. Cord water content and regional spinal cord blood flow (RSCBF, ${ }^{14} \mathrm{C}$-butanol distribution) were measured at seven cord levels after function had been reassessed following treatment. Untreated rats were given vehicle. The study was randomized and blinded. Results: Edema in heated segments was progressive over 24 hours, but was the same in treated vs untreated rats. RSCBF in heated segments was the same in treated vs uninjured controls at 6 and 24 hours. In untreated rats, RSCBF in the heated segment was elevated by $30 \%$ at 6 hours, but was the same as uninjured control by 24 hours. In the unheated segments of untreated rats, RSCBF was elevated at 24 hours. At 24 hours, RSCBF was lower in treated vs untreated rats at all levels, including the heated one. Limb function deteriorated equivalently in both groups. Conclusion: MP obviated the early rise in RSCBF in heated segments and the elevations in RSCBF in uninjured segments, but had no effect on cord edema or on limb function.
\end{abstract}

Keywords: radiofrequency heat; regional blood flow; spinal cord edema;

${ }^{14} \mathrm{C}$-butanol distribution; methylprednisolone.

\section{Introduction}

Glucocorticoids have been used clinically to treat acute spinal cord syndromes of diverse etiology, including trauma. Experimentally, there is evidence that glucocorticoids in appropriate dose are beneficial, at least in some of those circumstances. ${ }^{1,2}$ A recent clinical trial showed that patients with spinal cord injury had improved function provided they were treated with methylprednisolone (MP) in appropriate dose for 23 hours beginning within 8 hours of injury. ${ }^{3}$ The mechanisms of the protective action of glucocorticoids in injured or abnormal neural tissues are presently incompletely understood. Prominent among those mechanisms suggested by the experimental evid-

Correspondence: William W Monafo MD, Suite 6104 Queeny Tower, One Barnes Hospital Plaza, St Louis, MO 63110, USA. ence is an effect on regional blood flow that may be mediated either directly, by altering vascular tone; or indirectly, for example, by reducing the local generation of vasoactive substances. ${ }^{4}$ Another mechanism, the reduction of edema, is less widely favored than it was previously, based on recent experimental evidence..$^{5,6}$

At the molecular level, considerable evidence suggests that local tissue lipid peroxidation is an important injurious consequence of spinal cord contusion. ${ }^{7,8}$ Methylprednisolone may be beneficial in cord injury because of its antioxidant properties. ${ }^{3,9}$ Lipid peroxidation also occurs locally immediately after burn injury; and antioxidant therapy has benefit in experimental burns. ${ }^{10,11}$ A model of cord injury which does not mechanically disrupt blood vessels or axons would therefore be potentially advantageous for the study of those 
secondary phenomena which are shared by both contusive and thermal tissue injury mechanisms.

In these experiments, we examined the short term effects of high dose MP on regional spinal cord blood flow (RSCBF) and on segmental cord edema formation in rats in which a short segment of the lumbar spinal cord had been heated briefly by the passage of radiofrequency (RF) current. The short-term functional neurological status of the hind limb was assessed during the first 24 hours after injury using two clinical scoring systems previously reported. ${ }^{12,13}$

\section{Materials and methods}

\section{Induction of spinal cord injury}

Male Sprague-Dawley rats weighing from 323 to $480 \mathrm{~g}$ were used. Fluothane $1.5 \%$ inhalation anesthesia was administered after intraperitoneal pretreatment with lactated Ringer's solution, $20 \mathrm{ml} / \mathrm{kg}$, and $0.004 \mathrm{mg} / \mathrm{kg}$ atropine subcutaneously. The fur was clipped from the lower belly wall, around the neck and from the upper posterior torso. A cystostomy was made through a small suprapubic incision using a Silastic catheter $(0.085$ in OD, Dow Corning) to prevent bladder overdistention and hemorrhage. A plastic Vialon catheter (1.1 mm OD, Deseret Medical) was inserted into the left jugular vein through a short cervical incision.

Through a short dorsal incision, the T12-L2 spinous, accessory, mammillary (or lateral) and transverse processes were exposed by dissecting the surrounding muscles. A $1 \mathrm{~mm}$ laminectomy was performed at T12 using a power drill with a burr bit. The intact dura was carefully depressed from the bone by blunt dissection and a $0.225 \mathrm{~mm}$ diameter thermocouple microprobe (IT-23, Sensortek, Inc, time constant 0.005 second) was inserted through the laminectomy into the epidural space and advanced caudally so that its tip was at the T13-L1 vertebral interspace. The microprobe was connected to a digital thermometer (BAT-8, Bailey Instrument Co).

A U-shaped clear plastic chamber, the parallel limbs of which were $15 \mathrm{~mm}$ apart, tabricated to contain $8 \times 5 \mathrm{~mm}$ copper electrodes wired to a RF generator (Henry Company, Model 100D) was inverted and positioned over the exposed spinal column at the T12-L1 level. The chamber, positioned within the cavity created by the muscle dissection, was filled with lactated Ringer's solution warmed to $37^{\circ} \mathrm{C}$.

Radiofrequency current $(2 \mathrm{MHz})$ was then passed through the $5 \mathrm{~mm}$ in length segment of spinal column and spinal cord contained within the electrodes by manipulating the power output of the RF generator. The desired temperature within the spinal canal $\left(47^{\circ} \mathrm{C}\right)$ was reached within $40-$ 80 seconds. Temperatures were recorded at 20 -second intervals. The temperature within the heated segment was maintained for 10 minutes, after which the wound was irrigated with room temperature lactated Ringer's solution. The chamber was then removed, the position of the thermocouple microprobe confirmed and the wound sutured. The fluothane anesthesia was discontinued.

\section{Randomization of treatments}

Provided that the hind limb neurological function 2 hours following injury was appreciably impaired, as evident from a neurological impairment score (NIS, see below) of between 6 and 12, the rats were randomly assigned by lottery to one of the control or treatment groups. Approximately 50\% of rats were sacrificed at this stage by pentobarbital overdose because they did not meet this criterion. Test rats, individually caged, were treated with intravenous MP sodium succinate in lactated Ringer's solution beginning 2 hours after injury with a bolus injection of $30 \mathrm{mg} / \mathrm{kg}$ of a solution containing $2 \mathrm{mg} / \mathrm{ml}$. In rats randomized for study at 24 hours, a continuous infusion of MP $(3 \mathrm{mg} / \mathrm{ml})$ at the rate of $5.4 \mathrm{mg} / \mathrm{kg} / \mathrm{hr}$ was instituted 1 hour later using a syringe pump (Model 355, Sage Instruments). In rats randomized for study at 6 hours, a second bolus of MP, $16.2 \mathrm{mg} / \mathrm{kg}$ was given 1 hour later $(5.4 \mathrm{mg} / \mathrm{kg} \times 3 \mathrm{hr})$. Control rats were given equivalent volumes of lactated Ringer's solution. All infusions were continued until further studies were performed. Rats 
studied after 24 hours were given the MP through the jugular venous catheter, which was tunnelled to exit the skin at the nape of the neck and attached to a swivel/spring device to prevent dislodgement.

\section{Additional controls}

In 12 other rats, measurements of spinal cord water content $(n=6)$ and of RSCBF $(n=6)$ were performed 2 hours following laminectomy alone and after a normal neurological status had been verified. These rats served as uninjured controls (group 1). The same two measurements were also done in 12 rats that had undergone cord injury 2 hours previously and whose neurological scores using the NIS were also within the range 6-12 (group 2). This group was included to determine a pretreatment baseline for comparison to data obtained later following injury.

\section{Measurements at 6 or 24 hours}

The rats were anesthetized with a single intraperitoneal injection of pentobarbital, $50 \mathrm{mg} / \mathrm{kg}$, following pretreatment with $0.004 \mathrm{mg} / \mathrm{kg}$ atropine subcutaneously and $10 \mathrm{ml} / \mathrm{kg}$ of lactated Ringer's solution intravenously.

Through small cervical and femoral incisions, plastic Vialon catheters were inserted into the right carotid artery and the right jugular vein $(1.1 \mathrm{~mm}$ OD) and the left femoral artery $(0.7 \mathrm{~mm}$ OD). The carotid catheter tip was in the ascending aorta, that of the jugular catheter at the superior vena cava, that of the femoral catheter at the external iliac artery. Mean arterial blood pressure (MAP) was measured by connecting the femoral catheter to a Statham 23 ID transducer positioned at heart level and a Tektronix Model \#414 pressure monitor. Arterial blood $\mathrm{PaO}_{2}, \mathrm{PaCO}_{2}$ and $\mathrm{pH}$ were determined immediately prior to the performance of blood flow measurements using an Instrumentation Laboratory System 1301 blood gas analyzer. Rectal temperature was monitored and maintained near $37^{\circ} \mathrm{C}$ using either a heating blanket or an infrared lamp. The interval between pentobarbital administration and the subsequent measure- ment of either RSCBF or of spinal cord water content was controlled.

\section{Regional blood flow}

Regional blood flow in various levels of the spinal cord was measured using the ${ }^{14} \mathrm{C}$ butanol 'indicator-fractionation' method we have described previously. ${ }^{14}$ Twenty-five $\mu \mathrm{Ci}$ of ${ }^{14} \mathrm{C}$-butanol were rapidly injected (less than 1 second) through the jugular catheter 5 seconds after a constant rate of arterial hemorrhage had been visually verified from the previously declamped femoral catheter. Fifteen seconds after the indicator had been injected, $1.0 \mathrm{ml}$ of cyanoacrylate glue was injected into the carotid catheter. This resulted in the formation of a dense intraluminal coagulum which extended from the aortic valve to beyond the aorto-iliac bifurcation and arrested blood flow nearinstantaneously. Simultaneously, the femoral catheter was clamped and the rat was killed with concentrated intravenous $\mathrm{KCl}$.

An extensive laminectomy was immediately performed. Seven segments of the spinal cord were procured at vertebral levels: C3-C5, T3-T5, T7-T9, T12, T13-L1 (heated level), L2-L3 and L4-L6, which represent the vertebral levels of spinal cord corresponding to spinal cord levels C3-C5, T3-T5, T7-9, L1-L2, L3-L6, S1-S4 and cauda equina, respectively. These samples were solubilized for 48 to 72 hours and their radioactivity determined by scintillation spectrophotometry. Regional spinal cord blood flow was calculated using the equation: $F_{t}=\left(Q_{t} F_{a}\right) /$ $\left(Q_{a} M_{t}\right) \times 100$ where:
$F_{t}$ is regional blood flow $\left(\mathrm{ml} \mathrm{min}^{-1}\right.$ $100 \mathrm{~g}^{-1}$ )
$F_{a}$ is rate of external hemorrhage (ml $\min ^{-1}$ )
$Q_{t}$ is indicator content in the tissue $\left(\mathrm{cpm} \mathrm{g}^{-1}\right)$
$Q_{a}$ is indicator content in the arterial blood (cpm g $\left.{ }^{-1}\right)$
$M_{t}$ is sample weight $(\mathrm{g})$.

The theoretical basis and validation of this methodology and the derivation of this equation from the Fick principle is given in detail in previous publications. ${ }^{14,15}$ 
Measurements of spinal cord water content These rats were killed by pentobarbital overdose. An extensive laminectomy was performed immediately. Seven segments of the spinal cord were procured at the same levels as those obtained for the RSCBF measurement. These samples were weighed immediately (wet weight), then oven-dried to constant weight for at least 24 hours. Water content (WC) was calculated from the formula $\% \mathrm{WC}=$ (wet weight - dry weight)/wet weight 100 .

\section{Clinical neurological function}

Assessment of the functional status of the hind limbs and tail was carried out by an experienced observer blinded to the treatment proposed or in progress at 2 hours after injury, prior to initiating treatment in all rats and also immediately before the performance of physiological measurements at either 6 or 24 hours after injury.

This assessment consisted of (1) a neurological assessment score (NIS), modified slightly from LeMay et al and outlined in Table I (normal $=<3$ ); ${ }^{16}$ (2) a corrected, combined behavioral score (CCBS) as reported by Gale et al ${ }^{12}$ and later modified by Kerasidis et $a^{13}$ (Table II). Scores from each hind limb were recorded separately. The two scoring systems were used with the aim of minimizing the appreciable inherent error in evaluating neurological function in experimental animals.

\section{Physiological variables}

Body weight, rectal temperature and pentobarbital anesthetic times were recorded. Measurements of RSCBF were immediately preceded by determinations of the MAP and of arterial blood $\mathrm{PaO}_{2}, \mathrm{PaCO}_{2}$ and $\mathrm{pH}$.

\section{Data analysis}

All data are given as the mean and standard error of the mean. Parametric data were analyzed on the Washington University main frame computer by analysis of variance followed by the use of statistical contrasts. The nonparametric data resulting from the neurological scoring systems described were analyzed using the Wilcoxon
Table I Neurological impairment score (NIS)

\begin{tabular}{|c|c|}
\hline Test & Points \\
\hline \multicolumn{2}{|l|}{ Walking with hind limbs (HL) } \\
\hline No evidence of deficit & 0 \\
\hline $\begin{array}{l}\text { Toes flat under body when walk- } \\
\text { ing but ataxia exists }\end{array}$ & 1 \\
\hline Knuckle walks & 2 \\
\hline $\begin{array}{l}\text { Movement of HL but unable to } \\
\text { knuckle walk }\end{array}$ & 3 \\
\hline No movement, drags HL & 4 \\
\hline \multicolumn{2}{|l|}{ Horizontal rope } \\
\hline $\begin{array}{l}\text { Grasps rope and pulls up with HL } \\
\text { Raises HL and grasps rope }\end{array}$ & 0 \\
\hline without pulling & 1 \\
\hline Raises HL but cannot grasp rope & 2 \\
\hline Does not raise $\mathrm{HL}$ & 3 \\
\hline \multicolumn{2}{|l|}{ Screen } \\
\hline $\begin{array}{l}\text { HL grasp screen }{ }^{a} \text { to } 180^{\circ} \text { for more } \\
\text { than } 5 \mathrm{~s}\end{array}$ & 0 \\
\hline $\begin{array}{l}\text { HL grasp screen to } 180^{\circ} \text { for less } \\
\text { than } 5 \mathrm{~s}\end{array}$ & 1 \\
\hline $\begin{array}{l}\text { HL grasp screen past vertical but } \\
\text { not to } 180^{\circ}\end{array}$ & 2 \\
\hline $\begin{array}{l}\text { HL fall from screen past vertical } \\
\left(270^{\circ}-180^{\circ} \text { range }\right)\end{array}$ & 3 \\
\hline $\begin{array}{l}\text { HL fall from screen before vert- } \\
\text { ical }\left(0^{\circ}-270^{\circ} \text { range }\right)\end{array}$ & 4 \\
\hline \multicolumn{2}{|l|}{ Pain sensation $(\mathrm{HL})$} \\
\hline Withdrawal to toe pinch & 0 \\
\hline $\begin{array}{l}\text { Squeals to toe pinch but does not } \\
\text { withdraw }\end{array}$ & 1 \\
\hline No reaction to toe pinch & 2 \\
\hline \multicolumn{2}{|l|}{ Pain sensation (Tail) } \\
\hline Withdrawal to tail pinch & 0 \\
\hline $\begin{array}{l}\text { Squeals to tail pinch but does no: } \\
\text { withdraw }\end{array}$ & 1 \\
\hline No reaction to tail pinch & 2 \\
\hline
\end{tabular}

a A plastic screen with $1.2 \times 1.2 \mathrm{~cm}$ apertures. The round screening is $2 \mathrm{~mm}$ in diameter. Normal $<3$, maximum 15 .

rank sum test. An unpaired $t$ test was used when appropriate. The null hypothesis was rejected at $p<0.05$.

\section{Results}

Spinal cord water content (Table III, Fig 1) Two hours after injury, cord water content was unchanged at all levels compared to the uninjured controls.

By 6 hours after injury, the water content 
Table II The combined bchavioral score and its correction (CCBS)

\begin{tabular}{|c|c|c|c|}
\hline Test & Points & Motor score & Correction \\
\hline $\begin{array}{l}\text { Motor score } \\
\text { Normal walking } \\
\text { Walks with only mild deficit } \\
\text { Hind limbs (HL) can support weight } \\
\text { Frequent/vigorous movement in HL, no weight bearing } \\
\text { Barely perceptible movement in HL, no weight bearing } \\
\text { No movement in HL, no weight bearing }\end{array}$ & $\begin{array}{r}0 \\
5 \\
15 \\
25 \\
40 \\
45\end{array}$ & 15 & $\begin{array}{l}+10 \text { points for any two: } \\
\text { Abnormal swim test } \\
\text { Abnormal pain withdrawal } \\
\text { Inclined plane score } \leqslant 40^{\circ} \\
-10 \text { points: } \\
\text { Hot plate response lacenty }<60 \\
+10 \text { points for any two: }\end{array}$ \\
\hline $\begin{array}{l}\text { Toe spread } \\
\text { Normal full toe spread } \\
\text { Partial spreading of toes } \\
\text { No spreading of toes }\end{array}$ & $\begin{array}{l}0 \\
5 \\
5\end{array}$ & 25 & $\begin{array}{l}\text { Inclined plane score } \leqslant 30^{\circ} \\
\text { Abnormal toe spread response } \\
\text { Abnormal extension withdrawal } \\
-10 \text { points: }\end{array}$ \\
\hline $\begin{array}{l}\text { Righting } \\
\text { Normal righting counter to direction of the roll } \\
\text { Weak/delayed attempt or rights in the direction of the roll } \\
\text { No attempt to right itself }\end{array}$ & $\begin{array}{l}0 \\
5 \\
5\end{array}$ & & $\begin{array}{l}\text { Inclined plane score } \geqslant 40^{\circ} \text { or } \\
\text { Swim test is normal } \\
+15 \text { points: } \\
\text { Inclined plane scorc }<30^{\circ} \text { and }\end{array}$ \\
\hline $\begin{array}{l}\text { Withdrawal reflex (extension, pressure, pain) } \\
\text { Normal withdrawal } \\
\text { Weak withdrawal } \\
\text { No withdrawal } \\
\text { Hyperactive withdrawal }\end{array}$ & $\begin{array}{r}0 \\
15 \\
15 \\
15\end{array}$ & 45 & $\begin{array}{l}\text { Righting is abnormal } \\
-15 \text { points: } \\
\text { Pressure/pain withdrawal is normal } \\
-5 \text { points: } \\
\text { Paw placement or extension withdrawal normal }\end{array}$ \\
\hline $\begin{array}{l}\text { Hot plate } \\
\text { Hind paw licking in less than } 30 \text { seconds } \\
>60 \text { seconds }\end{array}$ & $\begin{array}{l}0 \\
5\end{array}$ & & Pressure/pain withdrawal is normal \\
\hline $\begin{array}{l}\text { Paw placement when held at right angles to table top } \\
\text { Normal placement } \\
\text { Weak attempt to place paw } \\
\text { No attempt to place paw }\end{array}$ & $\begin{array}{l}0 \\
5 \\
5\end{array}$ & & \\
\hline $\begin{array}{l}\text { Swim-climb testing } \\
\text { Normal swimming and climbing using hind limbs } \\
\text { Abnormal swimming and climbing without using hind limbs }\end{array}$ & $\begin{array}{l}0 \\
5\end{array}$ & & \\
\hline $\begin{array}{l}\text { Inclined plane } \\
\text { Maintains position for } 5 \mathrm{~s} \text { at angle of } 50^{\circ}-60^{\circ} \\
\text { Maintains position for } 5 \mathrm{~s} \text { at angle of } 45^{\circ} \\
\text { Maintains position for } 5 \mathrm{~s} \text { at angle of } 35^{\circ}-40^{\circ} \\
\text { Maintains position for } 5 \mathrm{~s} \text { at angle of } \leqslant 30^{\circ}\end{array}$ & $\begin{array}{r}0 \\
5 \\
10 \\
15\end{array}$ & & \\
\hline
\end{tabular}


Table III Spinal cord water content (\% wet weight)

\begin{tabular}{|c|c|c|c|c|c|c|c|c|}
\hline \multicolumn{2}{|c|}{ Group } & \multirow{2}{*}{$\begin{array}{r}\mathrm{C} 3-\mathrm{C} 5 \\
68.8 \\
\pm 0.2\end{array}$} & \multirow{2}{*}{$\begin{array}{r}\mathrm{T} 3-\mathrm{T} 5 \\
68.1 \\
\pm 0.1\end{array}$} & \multirow{2}{*}{$\begin{array}{r}\mathrm{T} 7-\mathrm{T} 9 \\
68.4 \\
\pm 0.3\end{array}$} & \multirow{2}{*}{$\begin{array}{r}\mathrm{L} 1-\mathrm{L} 2 \\
69.0 \\
\pm 0.3\end{array}$} & \multirow{2}{*}{$\begin{array}{c}\begin{array}{c}\text { Injury level } \\
\text { L3-L6 }\end{array} \\
70.1 \\
\pm 0.2\end{array}$} & \multirow{2}{*}{$\begin{array}{r}\mathrm{S} 1-\mathrm{S} 4 \\
69.8 \\
\pm 0.2\end{array}$} & \multirow{2}{*}{$\begin{array}{c}\text { Cauda equina } \\
67.9 \\
\pm 0.2\end{array}$} \\
\hline 1) & $\begin{array}{l}\text { Uninjured control } \\
\text { (Laminectomy only, } \\
n=6 \text { ) }\end{array}$ & & & & & & & \\
\hline (2) & $\begin{array}{l}2 \text { hours after injury } \\
\text { Untreated }(n=6)\end{array}$ & $\begin{array}{r}69.0 \\
\pm 0.3\end{array}$ & $\begin{array}{r}68.2 \\
\pm 0.3\end{array}$ & $\begin{array}{r}68.0 \\
\pm 0.3\end{array}$ & $\begin{array}{r}68.9 \\
\pm 0.7\end{array}$ & $\begin{array}{r}71.2 \\
\pm 0.7\end{array}$ & $\begin{array}{r}69.4 \\
\pm 0.2\end{array}$ & $\begin{array}{r}66.7 \\
\pm 0.5\end{array}$ \\
\hline (3) & $\begin{array}{l}6 \text { hours after injury } \\
\text { Untreated }(n=8)\end{array}$ & $\begin{array}{r}68.8 \\
\pm 0.4\end{array}$ & $\begin{array}{r}68.3 \\
\pm 0.4\end{array}$ & $\begin{array}{r}68.6 \\
\pm 0.5\end{array}$ & $\begin{array}{r}70.5 \\
\pm 0.3\end{array}$ & $\begin{array}{c}73.6^{1} \\
\pm 0.4\end{array}$ & $\begin{array}{r}70.2 \\
\pm 0.6\end{array}$ & $\begin{array}{r}67.4 \\
\pm 0.4\end{array}$ \\
\hline (4) & $\begin{array}{l}6 \text { hours after injury } \\
\text { MP }^{\mathrm{a}} \text {-treated }(n=8)\end{array}$ & $\begin{array}{r}69.4 \\
\pm 0.2\end{array}$ & $\begin{array}{r}68.7 \\
\pm 0.3\end{array}$ & $\begin{array}{r}69.7 \\
\pm 0.3\end{array}$ & $\begin{array}{r}71.4^{2} \\
\pm 0.3\end{array}$ & $\begin{array}{l}73.8^{1} \\
\pm 0.6\end{array}$ & $\begin{array}{r}70.3 \\
\pm 0.3\end{array}$ & $\begin{array}{r}68.3 \\
\pm 0.4\end{array}$ \\
\hline (5) & $\begin{array}{l}24 \text { hours after injury } \\
\text { Untreated }(n=6)\end{array}$ & $\begin{array}{r}69.3 \\
\pm 0.3\end{array}$ & $\begin{array}{r}69.5^{3} \\
\pm 0.6\end{array}$ & $\begin{array}{r}69.8 \\
\pm 0.7\end{array}$ & $\begin{array}{r}72.0^{4} \\
\pm 1.0\end{array}$ & $\begin{aligned} & 74.5^{1} \\
\pm & 0.4\end{aligned}$ & $\begin{array}{r}70.5 \\
\pm 0.8\end{array}$ & $\begin{array}{r}68.4 \\
\pm 0.5\end{array}$ \\
\hline (6) & $\begin{array}{l}24 \text { hours after injury } \\
\text { MP-treated }(n=6)\end{array}$ & $\begin{array}{r}69.5 \\
\pm 0.3\end{array}$ & $\begin{array}{c}69.5^{3} \\
\pm 0.6\end{array}$ & $\begin{array}{r}69.7 \\
\pm 0.8\end{array}$ & $\begin{array}{r}72.7^{5} \\
\pm 1.1\end{array}$ & $\begin{array}{c}75.5^{1} \\
\pm 1.0\end{array}$ & $\begin{array}{r}71.0 \\
\pm 0.6\end{array}$ & $\begin{array}{r}68.8 \\
\pm 0.6\end{array}$ \\
\hline
\end{tabular}

${ }^{a}$ Methylprednisolone.

$p$ vs uninjured control: ${ }^{1}=0.0001 ;^{2}=0.01 ;{ }^{3}=0.03 ;{ }^{4}=0.004 ;{ }^{5}=0.0004$.

$\square$ A: uninjured control

B: $2 \mathrm{hr}$ after injury untreated

C: $6 \mathrm{hr}$ after injury untreated

D: $6 \mathrm{hr}$ after injury MP treated

E: $24 \mathrm{hr}$ after injury untreated

F: $24 \mathrm{hr}$ after injury MP treated
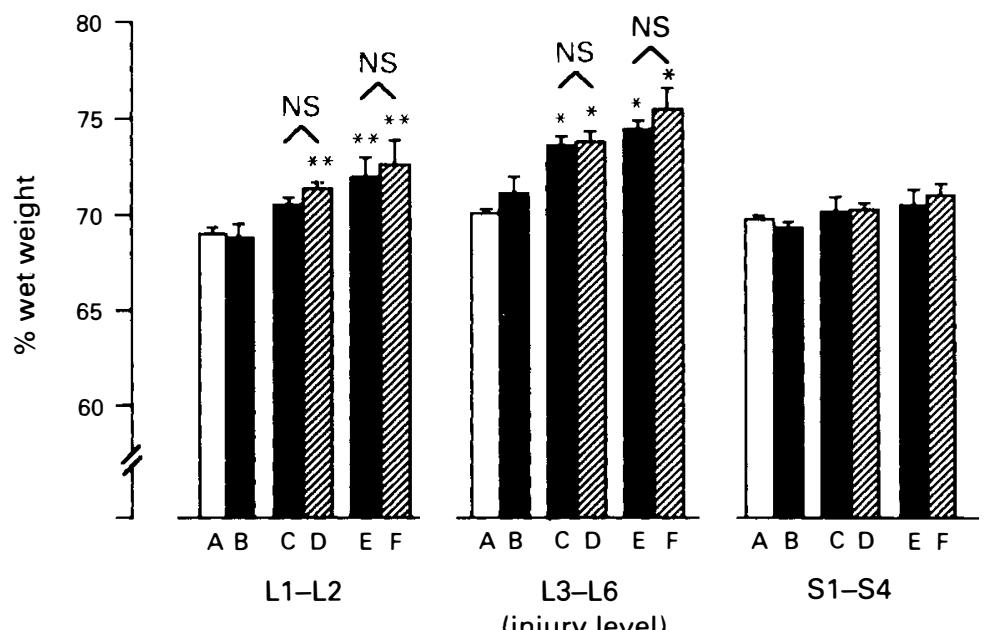

Spinal cord level

Figure 1 The changes in water content in the injured and adjacent spinal cord segments. Vs A: ${ }^{*} p<0.0001 ;{ }^{* *} p<0.01$. 
of the heated L3-L6 segment was increased compared to uninjured control in both the treated and untreated rats, but water content did not differ in treated vs untreated rats. In the L1-L2 cord segment adjacent cephalad to the heated one, water content was increased compared to the uninjured controls in the treated rats but not in the untreated ones.

Twenty-four hours after injury there was still no difference in water content in treated vs untreated rats in the heated L3-L6 segment, although in both groups the water content of this segment was more than that of the uninjured controls. In both groups, edema was now also evident in the adjacent L1-L2 segments and was similar in amount. There was a smaller, also equivalent increase in water content in the T3-T5 segment of both the treated and untreated rats.

\section{Regional blood flow (Table IV, Figs 1,2)}

By 2 hours after injury, RSCBF was elevated in untreated group 2 rats compared to uninjured control by from 24 to $35 \%$ at all cord levels, excepting only the cauda equina. Although pentobarbital anesthesia depresses RSCBF, ${ }^{4}$ this elevation was present despite the brief duration of anesthesia in this group.

By 6 hours after injury, RSCBF had returned to normal at all levels in untreated rats except at the heated L3-L6 segment, where it remained elevated at a value nearly identical to that present at 2 hours. In treated rats, however, RSCBF was no different from that in the uninjured controls either in the heated L3-L6 segment or in all the other segments cephalad to it. In the S1-S4 segment of the treated rats, RSCBF was depressed compared to that in the uninjured controls.

By 24 hours after injury, RSCBF in treated rats was lower than in the untreated rats at all levels of the cord. In the heated L3-L6 segment, RSCBF at 24 hours in treated rats was normal compared to uninjured control, but was less than that in untreated rats. Regional spinal cord blood flow was less than that of the uninjured controls in both the L1-L2 and S1-S4 segments adjacent to the heated one and in the $\mathrm{C} 3-\mathrm{C} 5$ segment. In the untreated rats, RSCBF was elevated compared to uninjured control at all unheated cord levels, the difference reaching significance only at C3-C5, T3-T5, T7-T9 and in the cauda equina.

\section{Neurological function (Table V)}

The uninjured controls had normal neurological function. At 2 hours following injury, both the NIS and the CCBS were clearly abnormal in the group 2 rats. There were no intragroup differences using either scoring system or when the scores from each of the hind limbs were compared separately. At 6 hours, there were no intergroup differences, nor was there a difference from the 2-hour scores in either the treated or untreated rats. At 24 hours, however, deterioration of function was present in both treated and untreated rats, but, as at 6 hours, there were no differences between groups.

\section{Physiological variables (Table VI)}

In the untreated rats at 24 hours (group 5), MAP was lower than in treated rats (group $6)$. The duration of pentobarbital anesthesia was less in the untreated group 2 rats than in the other groups. Otherwise, there were no intergroup differences that were judged to be of physiological significance.

\section{Discussion}

There is no ideal experimental model of spinal cord trauma. The clinical spectrum of cord injury is in itself diverse. ${ }^{4}$ Much spinal cord trauma research is based on the concept, backed by considerable experimental evidence, that the ultimate functional status is importantly influenced by secondary phenomena that may occur simultaneously or sequentially during minutes, hours or days after injury. The improvement in neurological function documented in the clinical trial of MP treatment already alluded to supports that concept and provides as well another important reason to investigate the mechanisms of MP action in the posttraumaic period.

One of the most widely held concepts and one supported by considerable evidence 
Table IV Regional spinal cord blood flow $\left(\mathrm{ml} \mathrm{min}^{-1} 100 \mathrm{~g}^{-1}\right)$

\begin{tabular}{|c|c|c|c|c|c|c|c|}
\hline & \multicolumn{7}{|c|}{ Spinal cord level } \\
\hline & $\mathrm{C} 3-\mathrm{C} 5$ & $\mathrm{~T} 3-\mathrm{T} 5$ & T7-T9 & $\mathrm{L} 1-\mathrm{L} 2$ & $\begin{array}{l}\text { Injury level } \\
\text { L3-L6 }\end{array}$ & $\mathrm{S} 1-\mathrm{S} 4$ & Cauda equina \\
\hline $\begin{array}{l}\text { Group } \\
\text { (1) Uninjured control } \\
\text { (Laminectomy only, }(n=6)\end{array}$ & $\begin{array}{r}62.3 \\
+3.1\end{array}$ & $\begin{array}{r}50.4 \\
\pm 1.3\end{array}$ & $\begin{array}{r}48.0 \\
\pm 1.5\end{array}$ & $\begin{array}{r}59.6 \\
+3.3\end{array}$ & $\begin{array}{r}62.9 \\
+4.0\end{array}$ & $\begin{array}{r}50.4 \\
\pm 2.6\end{array}$ & $\begin{array}{r}28.6 \\
\pm 1.8\end{array}$ \\
\hline$p, 1$ vs 2 & 0.0003 & 0.005 & 0.0023 & 0.005 & 0.0085 & 0.004 & \\
\hline $\begin{array}{l}2 \text { hours after injury } \\
\text { Untreated }(n=6)\end{array}$ & $\begin{array}{r}84.3 \\
\pm 5.0\end{array}$ & $\begin{array}{r}65.1 \\
\pm 4.6\end{array}$ & $\begin{array}{r}63.0 \\
\pm 3.6\end{array}$ & $\begin{array}{r}79.1 \\
\pm 3.3\end{array}$ & $\begin{array}{r}81.8 \\
\pm 5.5\end{array}$ & $\begin{array}{r}38.2 \\
\pm 3.2\end{array}$ & $\begin{array}{r}31.4 \\
\pm 0.87\end{array}$ \\
\hline $\begin{array}{l}\text { (3) hours after injury } \\
\text { Untreated }(n=8)\end{array}$ & $\begin{array}{r}61.6 \\
\pm 2.8\end{array}$ & $\begin{array}{r}52.9 \\
\pm 2.2\end{array}$ & $\begin{array}{r}53.8 \\
\pm 2.1\end{array}$ & $\begin{array}{r}65.7 \\
+2.4\end{array}$ & $\begin{aligned} & 82.5^{1} \\
\pm & 3.3\end{aligned}$ & $\begin{array}{r}46.2 \\
\pm 1.6\end{array}$ & $\begin{array}{r}37.1 \\
\pm 3.2\end{array}$ \\
\hline$p, 3$ vs 4 & & & & & 0.03 & & \\
\hline 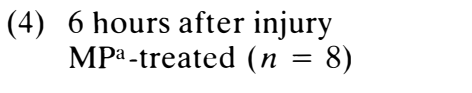 & $\begin{array}{r}60.7 \\
\pm 3.1\end{array}$ & $\begin{array}{r}51.2 \\
\pm 2.3\end{array}$ & $\begin{array}{r}52.5 \\
\pm 3.4\end{array}$ & $\begin{array}{r}59.4 \\
\pm 3.9\end{array}$ & $\begin{array}{r}69.4 \\
\pm 4.4\end{array}$ & $\begin{array}{l}41.9^{2} \\
\pm 2.5\end{array}$ & $\begin{array}{r}36.6 \\
\pm 2.3\end{array}$ \\
\hline $\begin{array}{l}24 \text { hours after injury } \\
\text { Untreated }(n=6)\end{array}$ & $\begin{array}{l}80.0^{3} \\
\pm 6.5\end{array}$ & $\begin{array}{r}69.8^{4} \\
\pm 6.1\end{array}$ & $\begin{aligned} & 69.7^{5} \\
\pm & 4.7\end{aligned}$ & $\begin{array}{r}69.3 \\
+3.9\end{array}$ & $\begin{array}{r}64.4 \\
\pm 6.2\end{array}$ & $\begin{array}{r}57.0 \\
\pm 2.6\end{array}$ & $\begin{array}{c}51.8^{5} \\
\pm 5.5\end{array}$ \\
\hline$p, 5$ vs 6 & 0.0001 & 0.0001 & 0.0001 & 0.0001 & 0.048 & 0.0001 & 0.0003 \\
\hline $\begin{array}{l}24 \text { hours after injury } \\
\text { MP-treated }(n=6)\end{array}$ & $\begin{array}{l}46.6^{6} \\
\pm 1.5\end{array}$ & $\begin{array}{r}44.3 \\
\pm 1.4\end{array}$ & $\begin{array}{r}45.4 \\
\pm 1.7\end{array}$ & $\begin{array}{r}46.2^{7} \\
\pm 3.4\end{array}$ & $\begin{array}{r}50.5 \\
\pm 4.0\end{array}$ & $\begin{aligned} & 39.8^{7} \\
\pm & 3.7\end{aligned}$ & $\begin{array}{r}33.1 \\
\pm 3.1\end{array}$ \\
\hline
\end{tabular}

${ }^{a}$ Methylprednisolone.

$p$ vs uninjured control: ${ }^{1}=0.0039 ;{ }^{2}=0.03 ;{ }^{3}=0.003 ;{ }^{4}=0.0003 ;{ }^{5}=0.0001 ;{ }^{6}=0.008 ;{ }^{7}=0.013$. 


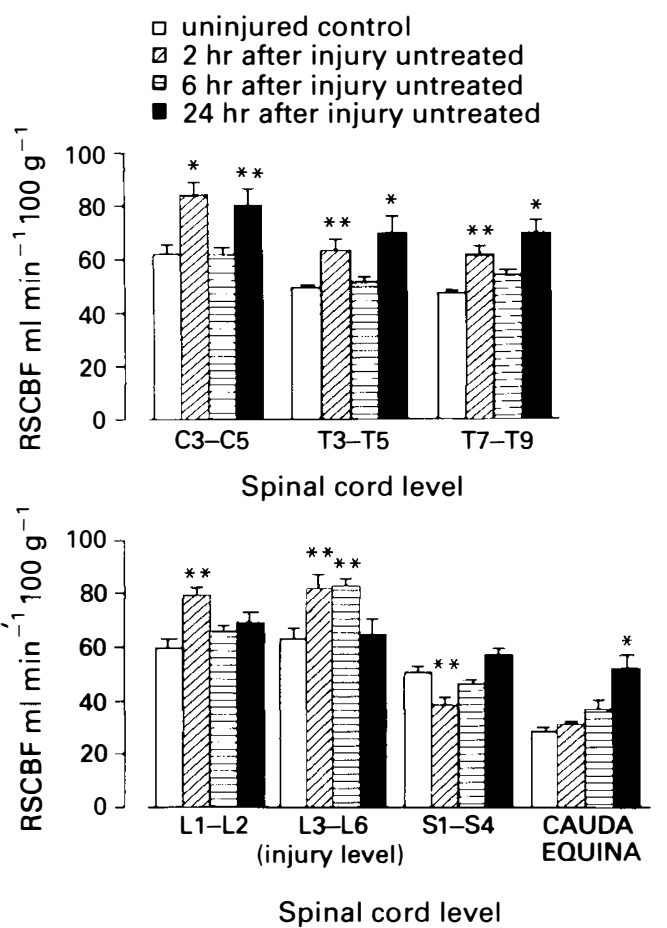

Figure 2 The changes in RSCBF in uninjured control and in injured, untreated rats. Note the tendency to biphasic elevation of RSCBF at 2 and 24 hours after injury in the three most cephalad cord segments. Vs uninjured control: ${ }^{*} p<0.001 ;{ }^{* *} p<0.01$.

is that spinal cord ischemia contributes importantly to the damage caused by trauma, noting in this regard the important distinction between ischemia, which connotes tissue metabolic impairment, and mere hypoperfusion. ${ }^{17-20} \mathrm{~A}$ partial list of other secondary phenomena in addition to ischemia includes the generation of eicosanoids, ${ }^{21.22}$ free radicals, ${ }^{1}$ the induction of lipid peroxidation ${ }^{23}$ and intracellular ionic perturbations. ${ }^{2}$ The time course, relative importance and the interactions among these factors, which are potentially amenable to therapy, are presently largely unknown or at best incompletely understood.

The mechanism of injury in the present model is clearly dissimilar to that usually occurring clinically, excepting perhaps in high voltage electrical injury. This model also differs in several significant aspects from those most often used previously,
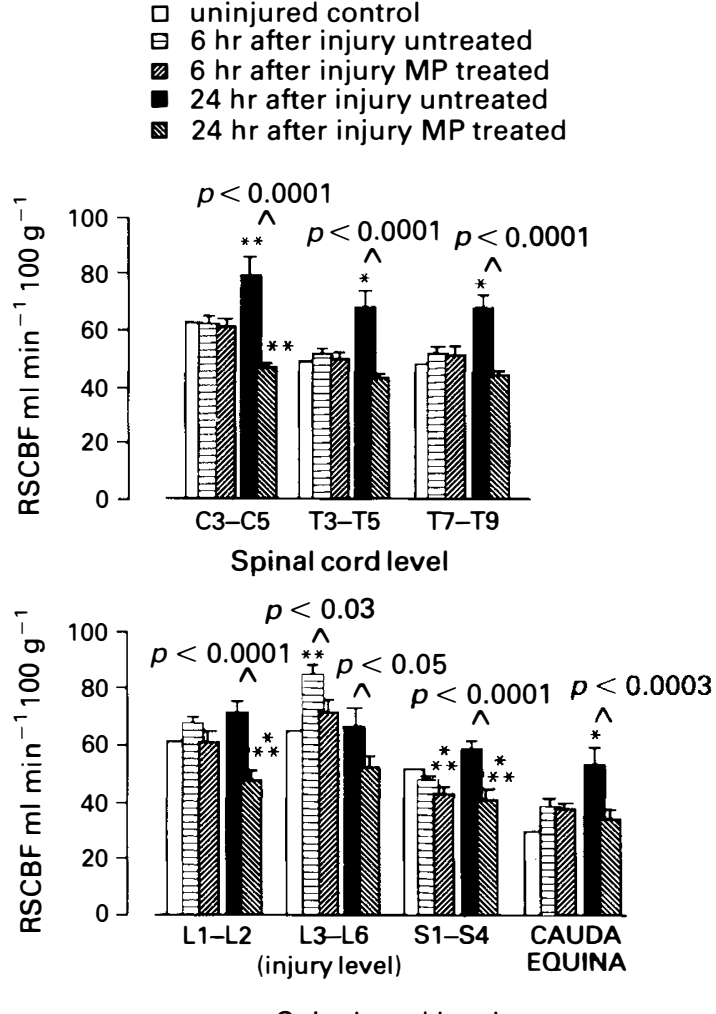

Spinal cord level

Figure 3 The effect of methylprednisolone treatment (MP) on RSCBF. Vs uninjured control: ${ }^{*} p<0.001 ;{ }^{* *} p<0.01 ;{ }^{* * *} p<0.05$.

namely impact or compression, but it is not associated with spinal shock or respiratory dysfunction and avoids mechanical disruption or occlusion of large blood vessels and neural structures. Also, major changes in MAP do not occur during or immediately following injury with the time-temperature coefficient used here.

There is consensus that the tissue injury resulting from the passage of radiofrequency current is the result of the heat generated. ${ }^{24,25}$ In the present model, progressive deterioration of neurological function occurred (Table V). The model therefore permits the investigation of secondary phenomena which appear, at least in part, to be shared, as lipid peroxidation is operative after both contusive spinal cord trauma and thermal injury to nonneural soft tissue. ${ }^{7,26}$ We do not yet have biochemical evidence supporting a role for 
Table V Neurological function

\begin{tabular}{|c|c|c|c|c|c|c|c|}
\hline \multirow{3}{*}{\multicolumn{2}{|c|}{ Group }} & \multicolumn{6}{|c|}{ Time after injury } \\
\hline & & \multicolumn{2}{|c|}{2 hours } & \multicolumn{2}{|c|}{5 hours } & \multicolumn{2}{|c|}{23 hours } \\
\hline & & $\mathrm{NIS}^{\mathrm{a}}$ & $\mathrm{CCBS}^{\mathrm{b}}$ & NIS & CCBS & NIS & CCBS \\
\hline (1) & $\begin{array}{l}\text { Uninjured control } \\
\text { (Laminectomy only, }(n=12)\end{array}$ & 1.8 & 0 & & & & \\
\hline (2) & $\begin{array}{l}2 \text { hours after injury } \\
\text { Untreated }(n=12)\end{array}$ & $\begin{aligned} & 8 \\
\pm & 1.0\end{aligned}$ & $\begin{array}{l}58 \\
\pm 8.0\end{array}$ & & & & \\
\hline (3) & $\begin{array}{l}6 \text { hours after injury } \\
\text { Untreated }(n=16)\end{array}$ & $\begin{array}{ll} & 8 \\
+ & 0.4\end{array}$ & $\begin{array}{l}57 \\
\pm 3.0\end{array}$ & $\begin{array}{l}9 \\
\pm 0.5\end{array}$ & $\begin{array}{l}67 \\
\pm 4.0\end{array}$ & & \\
\hline (4) & 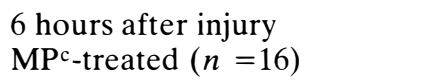 & $\begin{array}{l}8 \\
\pm 0.5\end{array}$ & $\begin{array}{l}58 \\
\pm 5.0\end{array}$ & $\begin{array}{l}9 \\
+0.8\end{array}$ & $\begin{array}{l}63 \\
\pm 6.0\end{array}$ & & \\
\hline (5) & $\begin{array}{l}24 \text { hours after injury } \\
\text { Untreated }(n=12)\end{array}$ & $\begin{array}{ll} & 8 \\
+ & 0.6\end{array}$ & $\begin{array}{l}58 \\
\pm 5.0\end{array}$ & & & $\begin{array}{r}13^{1} \\
\pm 0.4\end{array}$ & $\begin{array}{r}941 \\
\pm 2.0\end{array}$ \\
\hline (6) & $\begin{array}{l}24 \text { hours after injury } \\
\text { MP-treated }(n=12)\end{array}$ & $\begin{array}{l}7 \\
+0.6\end{array}$ & $\begin{array}{l}53 \\
\pm 6.0\end{array}$ & & & $\begin{aligned} & 12^{1} \\
\pm & 1.0\end{aligned}$ & $\begin{array}{r}84^{1} \\
\pm 7.0\end{array}$ \\
\hline
\end{tabular}

a Neurological impairment score.

${ }^{b}$ Corrected combined behavioral score.

cMethylprednisolone.

$1=p<0.01$ vs 2 hours after injury.

oxidative injury in the model described here, but the probability seems virtually certain, considering the numerous reports that have appeared supporting a role for oxidative injury after thermal burns, only some of which are cited in this report..$^{27-29}$

After contusive cord injury, tissue levels of the lipid peroxidation end-product malondialdehyde increase and cholesterol oxidation products appear; there are decreased levels of antioxidants such as $\alpha$-tocopherol and reduced ascorbate. ${ }^{7}$ Following burns, local and circulatory levels of malondialdehyde also increase and antioxidant therapy with allopurinol or ascorbic acid reduces local edema formation. ${ }^{10,11}$

In the present experiments, MP had no perceptible effect on the rate of early edema formation, either in the heated cord segment where edema was greatest or in any of the other cord segments examined. This finding agrees with one carefully controlled study in an impact injury model in which administration of glucocorticoid before or after injury did not reduce edema formation. ${ }^{5}$ It is important to note, however, that despite the absence of an effect of cortico- steroid treatment in either reducing cord edema or the rate at which it resolved, there was significantly more functional recovery observed in steriod-treated subjects during the 6 day follow up period. ${ }^{5.6}$

Treatment with MP had a definite effect on RSCBF, however, which was evident both at the injury site and elsewhere in the cord. Specifically, MP eliminated the 30\% increase in RSCBF in the heated segment that was present after 6 hours in untreated rats and was also present 2 hours after injury, prior to the initiation of treatment. Further, by 24 hours, although RSCBF in the heated L3-L6 segment was at the preinjury level in both the treated and untreated groups, RSCBF in the treated group was lower than that in untreated rats in that segment. In other words, RSCBF in the heated segment of treated rats was invariably less than that in the untreated rats and was never different from that in uninjured controls. Also, the tendency toward elevation of RSCBF in uninjured cord segments after 24 hours was not observed in the treated rats, in which RSCBF was less than that in the untreated rats at all levels and 
Table VI Physiological variables ${ }^{\mathrm{a}}$

\begin{tabular}{|c|c|c|c|c|c|c|c|c|}
\hline Gro & up & $\mathrm{MAPb}$ & Rectal & & Pentobarbital & $\mathrm{PaO}_{2}$ & $\mathrm{PaCO}_{2}$ & $\mathrm{pH}$ \\
\hline (1) & $\begin{array}{l}\text { Uninjured control } \\
\text { (Laminectomy only, } \\
n=6 \text { ) }\end{array}$ & $\begin{array}{l}123 \\
\pm 6\end{array}$ & $\begin{array}{r}36.6 \\
\pm 0.1\end{array}$ & $\begin{array}{r}428 \\
+\quad 15\end{array}$ & $\begin{array}{r}60 \\
\pm 9\end{array}$ & $\begin{array}{r}80.5 \\
\pm 2.0\end{array}$ & $\begin{array}{r}38.8 \\
\pm 2.6\end{array}$ & $\begin{array}{r}7.38 \\
\pm 0.02\end{array}$ \\
\hline (2) & $\begin{array}{l}2 \text { hours after injury } \\
\text { Untreated }(n=6)\end{array}$ & $\begin{array}{l}119 \\
\pm 6\end{array}$ & $\begin{array}{r}37.2 \\
\pm 0.2\end{array}$ & $\begin{array}{r}428 \\
\pm 13\end{array}$ & $\begin{array}{c}34^{1} \\
\pm 2\end{array}$ & $\begin{array}{r}89.2 \\
\pm 11.1\end{array}$ & $\begin{array}{r}36.4 \\
\pm 2.3\end{array}$ & $\begin{array}{r}7.37 \\
\pm 0.02\end{array}$ \\
\hline (3) & $\begin{array}{l}6 \text { hours after injury } \\
\text { Untreated }(n=8)\end{array}$ & $\begin{array}{r}84 \\
\pm 7\end{array}$ & $\begin{array}{r}37.7 \\
\pm 0.2\end{array}$ & $\begin{array}{r}386 \\
\pm 17\end{array}$ & $\begin{array}{r}61 \\
\pm 1\end{array}$ & $\begin{array}{r}94.2 \\
\pm 10.5\end{array}$ & $\begin{array}{r}32.6 \\
\pm 0.8\end{array}$ & $\begin{array}{r}7.40 \\
\pm 0.02\end{array}$ \\
\hline (4) & $\begin{array}{l}6 \text { hours after injury } \\
\text { MPc-treated }(n=8)\end{array}$ & $\begin{array}{r}81 \\
\pm 3\end{array}$ & $\begin{array}{r}37.3 \\
\pm 0.1\end{array}$ & $\begin{array}{r}380 \\
+\quad 11\end{array}$ & $\begin{array}{r}57 \\
\pm 1\end{array}$ & $\begin{array}{r}95.9 \\
\pm 8.4\end{array}$ & $\begin{array}{r}34.0 \\
\pm 0.6\end{array}$ & $\begin{array}{r}7.37 \\
\pm 0.02\end{array}$ \\
\hline (5) & $\begin{array}{l}24 \text { hours after injury } \\
\text { Untreated }(n=6)\end{array}$ & $\begin{array}{l}65^{2} \\
\pm 2\end{array}$ & $\begin{array}{r}37.1 \\
\pm 0.2\end{array}$ & $\begin{array}{r}392 \\
\pm 6\end{array}$ & $\begin{array}{r}60 \\
\pm 2\end{array}$ & $\begin{array}{r}70.2 \\
\pm 3.7\end{array}$ & $\begin{array}{r}36.8 \\
\pm 1.0\end{array}$ & $\begin{array}{r}7.37 \\
\pm 0.01\end{array}$ \\
\hline (6) & $\begin{array}{l}24 \text { hours after injury } \\
\text { MP-treated }(n=6)\end{array}$ & $\begin{array}{r}82 \\
\pm 4\end{array}$ & $\begin{array}{r}37.3 \\
\pm 0.1\end{array}$ & $\begin{array}{l}366^{3} \\
\pm 8\end{array}$ & $\begin{array}{r}58 \\
\pm 2\end{array}$ & $\begin{array}{r}82.5 \\
+5.5\end{array}$ & $\begin{array}{r}33.5 \\
\pm \quad 1.3\end{array}$ & $\begin{aligned} & 7.42^{3} \\
\pm & 0.01\end{aligned}$ \\
\hline
\end{tabular}

a Data from rats in which RSCBF was measured.

${ }^{b}$ Mean arterial blood pressure.

${ }^{c}$ Methylprednisolone.

${ }^{1} p<0.01$ vs all other groups; ${ }^{2} p<0.01$ vs $6 ;{ }^{3} p<0.05$ vs 5 .

was lower than in the uninjured controls in the $\mathrm{C} 3-\mathrm{C} 5, \mathrm{~L} 1-\mathrm{L} 2$ and $\mathrm{S} 1-\mathrm{S} 4$ segments.

These data tend to confirm prior experimental evidence, obtained mainly from impact or compression models and using other methods of measuring RSCBF, indicating that high dose MP as used here affects RSCBF following injury. ${ }^{2.30}$ When injury was severe in those models (as it was here, as evidenced by the 24-hour neurological scores) MP was found to blunt or prevent an early fall in RSCBF. ${ }^{2}$ In the present model, however, RSCBF was elevated at 2 and 6 hours after injury in the injured segment of the untreated rats and there was an apparent biphasic elevation in flow at 2 and 24 hours in most of the other, unheated segments.

In untreated rats, the directional changes in RSCBF were not necessarily similar in heated and uninjured segments. At 2 hours, RSCBF was elevated vs uninjured control by from 24 to $35 \%$ at all cord levels cephalad to and including the heated site, but was depressed at $\mathrm{S} 1-\mathrm{S} 4$ and unchanged in cauda equina. At 6 hours, RSCBF in the heated segment of untreated rats was still elevated by about $30 \%$, but flow in all remaining cord segments was then the same as in the uninjured controls. At 24 hours, RSCBF in all uninjured cord segments was elevated, while flow in the heated segment did not differ from uninjured control. The elevated flow in uninjured segments was present despite a MAP of $65 \mathrm{mmHg}$, well below the autoregulatory range in normal rat spinal cord. ${ }^{14}$

The present experiments provide no explanation as to the mechanism by which MP affects RSCBF after injury. The dose used greatly exceeds that necessary to activate corticosteroid receptors. ${ }^{3,9}$ During the brief 24-hour duration of these experiments, there was (not surprisingly) no evidence that MP favorably affected neurological function, which had deteriorated equivalently in both treated and untreated rats between the second and twenty-fourth hours following injury. (In the clinical trial of MP, the functional assessments that documented improvement were first performed 6 weeks following injury. $)^{3}$

Our previous experience using a minor variation of the present experimental model 
suggests that the injury is such that spontaneous improvement of function would be anticipated after approximately 4 weeks. ${ }^{31}$ Serial histological studies by others of spinal cords thermally injured somewhat more severely than in the present experiments (time-temperature coefficient $48^{\circ} \mathrm{C} \times 60$ minutes) have shown reconstitution of myelin sheaths and resolution of edema beginning at about 2 weeks after injury. ${ }^{32}$ These histologic findings are consistent with the clinical evidence of recovery that we observed previously at 1 month.

Whether the early changes in RSCBF attributable to MP therapy documented here have functional significance in the long term is presently unknown. Early edema accumulation in the spinal cord was not altered by MP treatment in this model. These experiments provide added support for the concept that high dose MP can affect RSCBF early after cord injury. Whether this effect is direct or indirect or whether it may be merely an epiphenomenon remains to be determined.

\section{Acknowledgement}

This research was supported by NIH Grant \#5 R01 GM33770.

\section{References}

1 Hall ED, Braughler JM (1982) Glucocorticoid mechanisms in acute spinal cord injury: A review and therapeutic rationale. Surg Neurol 18: 320-327.

2 Young W, Flamm ES (1982) Effect of high-dose corticosteroid therapy on blood flow, evoked potentials. and extracellular calcium in experimental spinal injury. J Neurosurg 57: 667-673.

3 Bracken MB, Shepard MJ, Collins WF, Holford TR, Young W. Baskin DS et al (1990) A randomized, controlled trial of methylprednisolone or naloxone in the treatment of acute spinal-cord injury. New Engl J Med 322: $1405-1411$.

4 Young W (1985) Blood flow, metabolic and neurophysiological mechanisms in spinal cord injury. In: Becker DP, Povlishock JT, editors. Central Nervous System Trauma Status Report-1985. National Institutes of Health, Bethesda, Maryland: 463.

5 Lewin MG, Hansebout RR, Pappius HM (1974) Chemical characteristics of traumatic spinal cord edema in cats. J Neurosurg 40: $65-75$.

6 Lewin MG, Pappius HM, Hansebout RR (1972) Effect of steroids on edema associated with injury of the spinal cord. In: Reulen HJ, Schürman K, editors. Steroids and Brain Edema. Springer-Verlag, Berlin/ Heidelberg/New York: 101.

7 Hall ED, Braughler JM (1986) Role of lipid peroxidation in post-traumatic spinal cord degeneration: A review. Cent Nerv Syst Trauma 3: 281-294.

8 Hall ED, Braughler JM, McCall JM (1988) New pharmacological treatment of acute spinal cord trauma. $J$ Neurotrauma 5: 81-89.

9 Braughler JM, Hall ED, Means ED, Waters TR, Anderson DK (1987) Evaluation of an intensive methylprednisolone sodium succinate dosing regimen in experimental spinal cord injury. J Neurosurg 67: 102-105.

10 Demling RH, LaLonde C (1990) Early postburn lipid peroxidation: Effects of ibuprofen and allopurinol. Surgery 107: 85-93.

11 Matsuda T, Tanaka H, Williams S, Hanumadass M, Abcarian H, Reyes H (1991) Reduced fluid volume requirement for resuscitation of third degree burns using high dose vitamin C. J Burn Care Rehabil 12: $525-532$.

12 Gale K, Kerasidis H, Wrathall JR (1985) Spinal cord contusion in the rat: Behavioral analysis of functional neurological impairment. Exp Neurol 88: 123-134.

13 Kerasidis H, Wrathall JR, Gale K (1987) Behavioral assessment of functional deficit in rats with contusive spinal cord injury. J Neurosci Methods 20: 167-189.

14 Sakamoto T, Shimazaki S, Monafo WW (1988) $\left[{ }^{14} \mathrm{C}\right]$ butanol distribution: A new method for measurement of spinal cord blood flow. Am J Physiol 255 (Heart Circ Physiol 24): H953-H959.

15 Sugimoto H, Monafo WW, Eliasson SG (1986) Regional sciatic nerve and muscle blood flow in conscious and anesthetized rats. Am J Physiol 251 (Heart Circ Physiol 20): H1211-H1216.

16 LeMay DR, Neal S, Neal S, Zelenock GB, D'Alecy LG (1987) Paraplegia in the rat induced by aortic cross-clamping: Model characterization and glucose exacerbation of neurologic deficit. J Vas Surg 6: 383-390.

17 Cawthon DF, Senter HJ, Stewart WB (1980) Comparison of hydrogen clearance and ${ }^{14}$ C-antipyrine autoradiography in the measurement of spinal cord blood flow after severe impact injury. J Neurosurg 52: $801-807$

18 Dow-Edwards D, DeCrescito V, Tomasula JJ, Flamm ES (1980) Effect of aminophylline and isoproterenol on spinal cord blood flow after impact injury. J Neurosurg 53: 385-390. 
19 Sandler AN, Tator $\mathrm{CH}$ (1976) Review of the effect of spinal cord trauma on the vessels and blood flow in the spinal cord. J Neurosurg 45: 638-646.

20 Senter HJ, Venes JL (1978) Altered blood flow and secondary injury in experimental spinal cord trauma. $J$ Neurosurg 49: 569-578.

21 Boullin DJ, Blaso WP, Mistry G, DuBoulay GH, Aitken V, Tagari P (1981) Role of prostacyclin in physiological control of the cerebral circulation in health and cerebrovascular disease. In: Cervós-Navarro A, Fritschka E, editors. Cerebral Microcirculation and Metabolism. Raven Press, New York: 205.

22 Saunders RD, Dugen LL, Demediuk P, Means ED, Horracks LA, Anderson DK (1978) Effects of methylprednisolone and the combination of $\alpha$-tocopherol and selenium on arachidonic acid metabolism and lipid peroxidation in traumatized spinal cord tissue. J Neurochem 49: 24-31.

23 Faden AI, Chan PH, Longar S (1987) Alterations in lipid metabolism, $\mathrm{Na}^{+}, \mathrm{K}^{+}$-ATPase activity, and tissue water content of spinal cord following experimental traumatic injury. J Neurochem 48: 1809-1816.

24 Brodkey JS, Miyazaki Y, Ervin FR, March VH (1964) Reversible heat lesions with radiofrequency current. A method of stereotactic localization. J Neurosurg 21: 49-53.

25 Letcher FS, Goldring S (1986) The effect of radiofrequency current and heat on peripheral nerve action potential in the cat. $J$ Neurosurg 29: 42-47.

26 Friedl HP, Till GO, Trentz O, Ward P (1989) Roles of histamine, complement and xanthine oxidase in thermal injury of skin. Am J Pathol 135: 203-217.

27 Oldham K, Giuce K, Till G, Ward P (1985) Activation of complement by hydroxyl radical in thermal injury. Surgery 104: 272-279.

28 Saez J, Ward P, Gunther B, Vivaldi E (1984) Superoxide radical involvement in the pathogenesis of burn shock. Circ Shock 12: 229-239.

29 Thomson PD, Till GO, Woolliscroft JO, Smith DJ, Prasad JK (1990) Superoxide dismutase prevents lipid peroxidation in burned patients. Burns 16: 406-413.

30 Anderson DK, Means ED, Waters TR, Green ES (1982) Microvascular perfusion and metabolism in injured spinal cord after methylprednisolone treatment. J Neurosurg 56: 106-113.

31 Sakamoto T, Monafo WW (1989) Naloxone in spinal cord injury. Surg Forum 40: 485-486.

32 Sasaki M, Ide C (1989) Demyelination and remyelination in the dorsal funiculus of the rat spinal cord after heat injury. J Neurocytol 18: 225-239. 